\title{
FLIPPED LEARNING: A DIGITAL PEDAGOGY FOR SUSTAINABLE LEARNING
}

\author{
Sonia Gouri \\ Academician \& Researcher, \\ KIET Group of Institutions, \\ Delhi-NCR-Gzb
}

Article DOI: https://doi.org/10.36713/epra5906

\begin{abstract}
Once Dr. Bob Kizlik had said that learning, regardless of how it is defined, is ultimately the responsibility of the learner, not the teacher. Today problem based learning with appropriate use of ICTs has emerged to achieve the objectives of learning in a more effective manner since teaching-learning process has also become learner-centered now. We are moving towards the new techniques of quality teaching by using digital pedagogy, a new way of engaging students with the curriculum. One such instructional strategy of teaching is a flipped class room- a type of blended learning that reverses the traditional learning environment by delivering instructional content, often online, outside of the classroom. Present paper focuses on the significance of using digital pedagogy \& flipped classroom in teaching-learning process, which changes homework activities into the classroom thereby, promotes sustainable learning since this is relevant and responsive to students' needs.
\end{abstract}

KEYWORDS- Flipped learning; Pedagogy, Digital; Sustainable

\section{INTRODUCTION}

Present paper is an attempt to present the concept of flipped learning as a tool for changing the mindset of people towards digital pedagogy for sustainable learning. When we talk about sustainability, we are talking about something that lives life-long, moreover, we are living in a rapidly changing era of globalization and digitalization where we are a touch away with rest of the world; we are talking about global citizenship and shared responsibility for handling global problems [1]. In this scenario the concept of sustainable learning where we learn to live within the environmental limits of our planet and to build a just, unbiased and peaceful society which is very much essential for the well-being of all, education also is not left untouched with digitalization where, equipped with new techniques, teachers are confident in their knowledge and understanding of the challenges being faced by society locally and globally and students are provided with the knowledge and skills to be confident through sustainable learning because only that approach will ensure sustainable learning environment where teaching learning process would become evidence-based, purposeful, relevant and responsive to students' needs [2].

The challenge for universities to survive and prosper in the early 21 st century is highlighted by Shore's argument that 'a new set of discourses has emerged around universities and their role that draws together different, often contradictory, agendas' heralding 'a shift towards a new, multi-layered conception in which universities are expected to fulfill a plethora of different functions' [3]. We are going through a paradigmatic shift in mindset towards teaching learning process as now we focus more on the need and problems of students rather than focusing on what we want to teach them. Once Dr. Bob Kizlik had said that learning, regardless of how it is defined, is ultimately the responsibility of the learner, not the teacher [4]. As we see in traditional pedagogical approach all the activities such as pre-decided learning materials, fixed deadlines and fixed pattern of assignments etc. are teachercentered but now problem-based learning with appropriate use of ICTs to improve the quality of 
teaching-learning process has emerged to achieve the objectives of learning in a more effective manner since it has become learner-centered now [5].

Earlier, the core objective of teaching was believed to pass on the information or knowledge to the brains of the students and to achieve this, many strategies were used during learning process, which are called teaching pedagogies [6]. Now, we are using digital pedagogy, which refers to the use of digital technologies to engage students with the curriculum and to promote learning [7]. It is a new way of learning and working with information and communication technology (ICT). Today almost all the educational institutions are moving towards the new techniques of quality teaching [8]. One such instructional strategy of teaching is a flipped classroom; it is a type of blended learning that reverses the traditional learning environment by delivering instructional content, often online, outside of the classroom [9]. It changes activities, including those that may have traditionally been considered homework, into the classroom thereby promoting sustainable learning since this provides students with the knowledge and skills to be confident and effective inclusive teachers since teachers are using these methods very effectively to facilitate the students in all possible manner. This approach to learning for sustainability is robust, demonstrable, evaluated and supported by educationist at all levels [10].

\section{SUSTAINABLE LEARNING THROUGH DigitALIZATION}

We know whatever we learn by doing stays for a longer period because we can assimilate that learning in an effective manner in our conduct and that is called sustainable learning. It as an inclusive practice for $21 \mathrm{st}$ Century Classrooms equipped with all kind of required knowledge and skills to be confident and effective inclusive teachers. These things are necessary for quality teaching, a teaching, which is based on evidence, purposeful, relevant, and responsive to the needs of students. Today teaching - learning process employs three overarching frameworks to examine inclusive practices in education: learning for all, teaching that matters and learning that lasts. It helps teachers to observe all students as budding learners and to judge the difficulties and variety of learning in the 21 st century. It focuses on a sustainable approach to inclusion; learning processes; teaching processes; differentiation; assessment to support teaching and learning; and life-long learning. Recent shift from traditional classroom teaching to digitalization in teaching learning process has encouraged dynamic learning, knowledge building, investigation, and exploration on the part of the learners, and which allow for distant communication as well as information sharing between teachers and/ or learners in special classroom locations. Digitalization in teaching learning process is an advanced concept of technologies that clarifies their role in classrooms in contrast to their wider use across institutions and learning centers.

\section{A. Terms Associated with Digital Technologies in Classroom are:}

- Bring your own device (BYOD): Students arrange their own device into the classroom for use as part of the learning process, cell phone is used to browse the internet as part of a research activity, greater range of technologies is available and is cost effective to institutions, but these technologies are sometime difficult to control and monitor. Some learners may have better devices than others and lack of teacher understanding \& training can also be a problem.

- E-portfolio: Students and teachers create electronic list of tasks that tracks their learning journey. Usually this is done online with multimedia files. Artwork of a student is presented through an e-portfolio. This includes scans of their sketches, photographs of displays and visits to galleries, written reflections, narrated videos of the learner at work and an audio logbook provides a way of quickly and seamlessly presenting a wide variety of material in different formats including details of process data security and confidentiality.

- Flipped classroom: Students discover new content before the lesson from online videos or resources and then apply this knowledge in more personalized work in the classroom for example learners watch a video at home about how sedimentary rocks are transformed into metamorphic rocks. They work in teams to make a diagram explaining this procedure of transformation. More time for activities promotes deeper understanding and reflection. Sometime learners do not understand or are not able to access the flipped material and misunderstandings arise that are not addressed in class because of lack of teacher understanding or training ensuring resources are up to date.

- Personal Learning Network (PLN): PLN is an individual's loose collection of links with other people or resources. The aim of such a network is to facilitate an exchange of ideas that supports learning. Links can be through, for example: 
online interest groups for example on Twitter and/or online and face-to-face courses access to a wide range of perspectives and expertise beyond the confines of the physical institution. We have data security, confidentiality, and accuracy of information access to the network.

- Virtual Learning Environment (VLE): VLE is an e-learning education system that is web-based but modeled on conventional face-to face education. It helps to access to various courses, their content, assignment, tutorial, external resources links etc. Moodle Blackboard is an easy way to collate and organize courses and information. We have flexibility of access, but software can limit course structure and it has high level of maintenance.

\section{B. Benefits of Digital Technologies in the Classroom are (87\%)}

- Digital Technologies in the Classroom can speed up dialogic and emancipatory applications. Students are active, engaged, and empowered participants in an interaction from which learning emerges. For example, learners working on a math's modeling program can start to have conversations about what they see on a computer screen without having to rely on terminology that they do not have till time. The teacher can concretize then in suitable language into the interaction as the discussion on topic develops. This is the teaching learning process in classroom. In emancipatory practice, the ideas of an individual student go beyond the learning given by the teacher or in syllabus as they depend on understanding received outside formal education. For example, in music classes students can use their own experience and knowledge of playing instruments or using technology to create their own recording environments like using cell phone.

- Various learning activities with the help of different technology can improve teaching learning process as on a topic two classes/sections can link up through internet to find out cultural differences about a specific issue such as global warming or energy supply. The teams can work together to develop understanding on the issue and its effect on communities and people by discussing with real people at various places. This can be done for a group or whole class through video conferencing.

- Digital technology becomes very interesting for students because it provides a significant alternative of involvement in teaching learning process. On the other hand, we find the tendency of becoming less confident in few students for the use of digital technologies during learning process. Therefore, we should ensure the learning of each student. Moreover, digital technology provides instant response for both the student and the teacher.

\section{Requisites \& Tools for the Digital Classroom for Enhancing Learning}

When we talk about digitalization in teaching learning process, it refers to the use of digital technologies to engage students with the curriculum to promote learning. There are various types of tech-based tools available to use in the classroom which are designed specifically for encouraging, enhancing, and managing learning viz. Google Classroom, Zoom, Microsoft Team, Socrative, Scratch, Prezi, SelfCAD, Quizlet / Quizlet Live, Adobe Spark Video, Khan Academy, Seesaw and Class Dojo etc. It is a new way of learning and working with information and communication technology (ICT). During teaching learning process through digitalization our learning is sustained for a longer period because of our higher sensory stimulation as we watch, listen, explore and learn by doing simultaneously. And for this:

- Students are encouraged to go through the various MOOCs courses.

- Online resources links are provided to the students.

- WhatsApp group are formed for collaborative learning.

- PPT, OHP, Videos, Workshops and Lab are included in teaching-learning process

\section{FLIPPED LEARNING}

Today almost all the educational institutions are moving towards the new techniques of quality teaching. One such instructional strategy of teaching is a flipped classroom by the educators who care more about their students and their success. The Flipped Classroom is the same as a normal classroom but instead of paying attention to lectures while in class and applying the new knowledge in their homework after class, learner will go through the lectures beforehand, and use the time of class to do their assignments. Teachers will not tell students what to study, how to study, when to study and how to establish that they studied. Teachers will only assist them in becoming self-directed learners. It is a type of blended learning that reverses the traditional learning environment by delivering instructional content, often online, outside of the classroom. It changes activities, including those that may have traditionally been considered homework, into the 
classroom thereby promoting sustainable learning since this provides students with the knowledge and skills to be confident and effective inclusive teachers since teachers are using these methods very effectively to facilitate the students in all possible manner by turning things upside down. In customary instructional model of teaching, a teacher gives lecture during class and then gives homework to do at home. This process is reversed in the flipped classroom. Requiring students to acquire foundational knowledge before class creates space during class for learning opportunities where students apply that knowledge. Bergmann and Sams pioneered this approach in 2007-2008 when they prerecorded all their lectures for students to watch as homework and then used class time to work problems and address areas where students were struggling [11]. Inexpensive technology for producing and posting online content (for example, screen casting software, YouTube) and high-speed Internet via laptops and mobile devices have served as a catalyst for the proliferation of this model within classrooms. A variety of instructional techniques can be applied in a flipped classroom; thus, "there is no such thing as the flipped classroom" [12].

A. One must focus on the following points while flipping a class:

- Flipping your class: Why do you want to flip a lesson? How will 'flipping' benefit your learners? How will it add value to your class? You must have clarity of these things before you flip your classroom.

- Begin with the difficult topic: Choose a topic your students struggle with. Share a clip, which discusses that topic and then employ the time of class to solve their queries and let students teach one another.

- Sufficient broadband access: Make sure that your students have good internet connectivity. If not, they should use the institution's computer lab after classes. If not possible, think of other ways your students can access video content or skip video content if it is not possible and use good oldfashioned print even.

- Time matters: Select those videos, which are short and comprehensive. If it is longer than 10 minutes, your students will not watch it. Another good rule is that 1-2 good videos are better than 5-6 mediocre ones.

- Teach students to view video: Do not believe that students know how to view topic-based videos. Go over with them how to watch a video. Students should watch the whole video. Then they should watch it again taking notes. Finally, when they watch, they can add more information to their notes.

- Make students accountable: If students do not have to demonstrate that they've watched the video, they won't. Let them prepare notes and count it for credit. Use formative assessment tools like a preclass quiz about the video at the beginning of class and ask students to share key ideas of the clip.

- Easy stuff outside of class: Do not show the video outside of class and then inside class. It spoils the objectives of flipped learning and valuable instructional time also. The point of flipped learning is to push easy stuff outside of class so you can save times for practice and other things.

- Do not repeat/ lecture again: Once students have watched the video before class and they know the content, do not repeat lecture again in class. Focus on the instructions to solve their errors or confusion.

- Engage learners in higher-level thinking (discussions of what-if scenarios, problem solving, analyzing a topic, summarizing key ideas.

- Evaluate students' knowledge of the key points of the topic and motivate them with more precise examples, problems and tasks. Help students who need it with assistance and more practice.

- Pay attention to language: Think about English language learners or those who are not good in English. Mostly the content of video remains in English language; therefore, at some point you need to motivate students to practice listening English-language videos. Make sure that the voice and language are understandable. Try to keep captioning feature on so that students may hear and see where they have problem the English. This will help with understanding.

- Start creating your own content: Begin by narrating Power Points; use Podomatic_to create free podcast; screen case with Echo 360 ; or use simple free tools like Zaption or Jing to create your own video.

- Video is not the only option students can interact with multimedia, experience something, read two opposing views in books or online about the same issue, and come ready in class for discussion. Flipped learning is not about video or technology. It is about making the best use of instructional time so that students may engage deeply with content.

- Do not Flip Out: Don't be overwhelmed, start small, keep it simple, and see how it goes. Have students find high-quality videos for you.

- The conventional setting of a class was all about the teacher and the tasks assigned in a teacher's 
way. All the methods were for the use of teachers to help them for the best delivery of instruction. The students were merely passive receivers of information. But in flipped classroom whoever entered a classroom knows that students are anything but passive. Their expected inquisitiveness makes them vigorously search for latest, and when they are enthusiastic about a subject they try to learn all there is to be learned about it.

\section{B. Flipped Classroom Benefits for student:}

- Flipped teaching learning process brings a shift in the focus from the teacher's needs to the student's need; therefore, it becomes a student-centered approach of teaching.

- When students come prepare with lecture in class and discuss the things in class, solve problems and try to apply their new knowledge in the class, they have a sense of creative satisfaction and acknowledgement.

- If students do not understand anything while doing homework, they stop doing it and frustrate. Whereas in flipped class they come prepared with their problems for discussion and things they have not understood, they can ask over and receive instant targeted solutions.

- At times, lecture time becomes insufficient for all the interaction and activities that unavoidably prompts from exploring subjects in a deeper manner. Flipped learning becomes very significant in handling those topics.

- Moreover, students who are absent due to any disease, or any other cause, can pace with their classmates easily with the flipped classroom model than with the customary classroom teaching model.

- Flipped Classroom is very beneficial for teachers also because today teachers are not the only source of knowledge for students. When a student has lots of information available from various sources, the role of a teacher becomes more important than ever. A teacher then needs to identify the individual learning needs of students and making sure that they are using exact information in their learning process.

- When students come in class after preparing lecture, it is hardly needed for teachers to speak much about content related questions rather students apply that knowledge and teachers assist students in practical application of concepts.

- A lecture can be revised and used many times as the students need that lecture. The flipped classroom provides more autonomy to teachers to choose upon like time spend for each activity and time given to each student. Teachers can schedule their time and pay appropriate attention to weak students, good performers, introvert, and extrovert students.

- Flipped learning offers more information for parents, who want to know what their wards are doing at school. This can also help in improving the communication between parents and teachers.

- The flipped classroom encourages teachers to provide a flexible and involving manner to share learning content, while keeping more control on students' learning and practice.

\section{CONCLUSION}

Norris et al. says that 'global society was undergoing a fundamental transition from the Industrial Age to the Information Age and that 'For higher education, this translated into using Information or Knowledge Age tools - pervasive information and communications technology - to meet the needs of this New Age: universal learning throughout life, personalized and suited to current needs' [13]. The flipped classroom seems to better respond to the learning needs of students living in today's ever more connected world. It is fruitful for students and teachers both as it creates curiosity among students for learning and saves valuable times of class room teaching for discussion and problem solving session with teachers. This approach to learning for sustainability is robust, demonstrable, evaluated and supported by educationist at all levels. This study is necessary selective but is a modest attempt to present the idea of flipped class room as an effective tool for sustainable learning thereby changing the mindset of people towards it.

\section{REFERENCES}

1. M.K. Kim, S.M. Kim, O Khera, and J. Getman, "The experience of three flipped classrooms in an urban university: an exploration of design principles. Internet and Higher Education", 22 pp 37-50. 2014

2. M.R. Lea and S. Jones, "Digital literacies in higher education: exploring textual and technological practice. Studies in Higher Education", 36 (94) pp 377-393. 2011

3. C. Shore, "Beyond the multiversity: neoliberalism and the rise of the schizophrenic university: Special issue on anthropologies of university reform. Social Anthropology", 18 (1) 15-29. 2010

4. T. Mayes, and $S$. de Freitas, "Learning and $e$ learning: the role of theory”. In H. Beetham. \& $R$. Sharpe (Eds.). "Rethinking pedagogy for a digital age”, London: Routledge. pp. 13-25. 2007

5. S. Mukerjee, "Agility: a crucial capability for universities in times of disruptive change and 
innovation", Australian Universities Review, 56 (1) pp 56-60. 2014

6. J.F. Strayer, "How learning in an inverted classroom influences cooperation, innovation and task orientation". Learning Environments Research, 15 (2) pp 171-193. 2012

7. E.B. Westermann, "A half-flippede classroom or an alternative approach? : Primary Sources and Blended Learning". Educational Research Quarterly, 38 (2) pp 43-57. 2014

8. Sarah Zappe, Robert Lieicht, John Messner, Thomas Litzinger, and Hyeon Woo Lee. "Flipping the classroom to explore active learning in a large undergraduate course" (In Proceedings, American Society for Engineering Education Annual Conference \& Exposition) 2009

9. N. Warter-Perez and J. Dong, "Flipping the classroom: How to embed inquiry and design projects into a digital engineering lecture." (In Proceedings of the 2012 ASEE PSW Section Conference) 2012

10. F. Strayer Jeremy, "The effects of the classroom flip on the learning environment: A comparison of learning activity in a traditional classroom and a flip classroom that used an intelligent tutoring system". PhD thesis, The Ohio State University. 2007

11. J. Bergmann \& A Sams, "Flip your classroom: Reach every student in every class every day". Washington, DC: International Society for Technology in Education. 2012

12. A Sams, "The flipped class: Shedding light on the confusion, critique, and hype". The Daily Riff. Retrieved from www.thedailyriff.com/articles/theflipped-class-shedding-light-on-theconfusioncritique-and-hype-801.php, 11 Nov. 2012,

13. D. Norris, R. Brodnick, P. Lefrere, J. Gilmour, and L. Baer, "Transforming in an age of disruptive change: Planning for Higher Education) 41 (2) Part 1: Back to the future, zooming to the present pp 18-32 and Part 2: Getting started, getting it done. pp 33-55. 2012 